\title{
CSR PROGRAM PT PERTAMINA BASED ON COMMUNITY EMPOWERMENT IN PEAT ECOTOURISM DEVELOPMENT
}

\author{
Nurjanah $^{1}$ and Samsir ${ }^{2}$ \\ 1,Jurusan Ilmu Komunikasi Fakultas Ilmu Sosial dan Politik, Universitas Riau \\ ${ }^{2}$ Jurusan Manajemen Fakultas Ekonomi dan Bisnis Universitas Riau \\ Jl. HR Soebrantas, Km 12,5 Pekanbaru 28293, Indonesia \\ E-mail: ${ }^{1}$ nurjanah@lecturer.unri.ac.id, ${ }^{2}$ samsir@lecturer.unri.ac.id,
}

\begin{abstract}
Environmental problems that require serious handling are the problem of land and forest fires, especially on peatlands which cause losses, especially economic and environmental aspects. Peatlands are a natural resource that has the potential to be utilized for the welfare of the community. Utilization of peatlands is not only for agriculture, plantations and residential land, but can be used as peat ecotourism. The large number of peatlands that were initially not utilized, and most of them became unproductive idle lands, can be managed properly and are able to contribute samsirto improving the welfare of the surrounding communities through the company's CSR program. This paper aims to analyze the management of the CSR program in the development of peat ecotourism in Bukit Batu DistrictPakning River.Researchers collected field data through interviews, observation and documentation. The results showed that the company's CSR program is directed at developing various community empowerment programs, aiming for the community to have the power, strength or ability in physical and material aspects, as well as economic aspects.Utilization of post-fire peatlands with community empowerment in the process of developing peatland ecotourism through the Peat Typical Tree Planting program on burned land, the development of the Environmental-Based School Curriculum program and the Peat Arboretum Development program. The management of the CSR program is carried out through the planning, implementation and evaluation stages. The management of the CSR program is analyzed throughCommunity Based Tourism (CBT) Model which is a tourism development planning strategy.
\end{abstract}

Keywords: Management; ecotourism; empowerment; peatlands

\section{PROGRAM CSR PT PERTAMINA BERBASIS PEMBERDAYAAN MASYARAKAT DALAM PENGEMBANGAN EKOWISATA GAMBUT}

\begin{abstract}
ABSTRAK. Permasalahan lingkungan yang memerlukan penanganan serius adalah masalah kebakaran lahan dan hutan terutama pada lahan gambut yang mengakibatkan kerugian terutama aspek ekonomidan lingkungan. Lahan gambut merupakan sumber daya alam yang sangat potensial dapat dimanfaatkan untuk kesejahteraan masyarakat. Pemanfaatanlahan gambut bukan hanya untuk pertanian, perkebunan danlahan pemukiman saja, tetapi dapat dimanfaatkan sebagai ekowisata gambut. Banyaknya lahan gambut yang awalnya tidak dimanfaatkan, dan sebagian besar menjadi lahan tidur yang tidak produktif, bisa dikelola dengan baik dan mampu berkontribusi meningkatkan kesejahteraan masyarakat disekitarnya melalui program CSR perusahaan. Tujuan penelitian untuk menganalisispengelolaan program CSR dalam pengembangan ekowisata gambut di Kecamatan Bukit Batu Sungai Pakning. pengumpulkan data lapangan melalui wawancara, observasi dan dokumentasi. Hasil penelitian menunjukkan bahwa program CSR perusahaan diarahkan pada pengembangan berbagai program pemberdayaan masyarakat, bertujuan agar masyarakat memiliki daya, kekuatan atau kemampuan pada aspek fisik dan material, serta aspek ekonomi.Pemanfaatan lahan gambut pasca kebakaran dengan pemberdayaan masyarakat dalam proses pengembangan ekowisata lahan gambut melalui program Penanaman Pohon Khas Gambut pada lahanlahan bekas terbakar, pengembangan program Kurikulum Sekolah Berbasis Lingkungan dan program Pengembangan Arboretum Gambut. Pengelolaan program CSR dilakukan melakui tahapan perencanaan, implementasi sampai tahap evaluasi. Pengelolaan program CSR dianalisis melalui Model Community Based Tourism (CBT) yang merupakan strategi perencanaan pengembangan kepariwisataan.
\end{abstract}

Kata kunci: Pengelolaan; ekowisata; pemberdayaan; lahan gambut

\section{INTRODUCTION}

Peatlands are a potential natural resource that can be utilized for human welfare. Indonesia is one of the countries with the fourth peatland area after Canada, the Soviet Union and the United States. It is estimated that the area of peatland in Indonesia is around 14.95 million hectares, which are spread across the islands of Sumatra, Kalimantan, Papua and Sulawesi.(Fahmuddin, et al: 2014). Indonesian people try to maximize the use of peatlands such as agriculture, monocultural plantations, residential land or other facilities. Utilization of peatlands will continue to increase, according to data on growth in peatland use in 2016 of $40 \%$ and will be $60 \%$ in 2030(Wahyunto, et al: 2014).

Current environmental problems that require serious handling are the problem of land and forest fires (karhutla) on peatlands which have caused huge losses to the community, especially in the aspects 
of the economy, environment, health, education and transportation. In 2015 there were 2.6 million hectares of fires and resulted in economic losses of US \$ 16.1 billion. The occurrence of forest and land fires is caused by many factors. According toPurnomo (2020)fires are started deliberately and carried out by neat organizations to get the maximum benefit from crop cultivation. This organized crime was further strengthened through local political contestation through regional head elections(Purnomo 2020).

The occurrence of forest and land fires in general is also caused by two things, intentionally and unintentionally. Fires are deliberately triggered mostly by burning to clear land and exploitation of natural resources. Meanwhile, accidental fires are caused more by hot weather, burning garbage, throwing cigarette butts, and other negligent acts. According to WALHI, forest and land fires in Riau are one of the annual disasters caused by human behavior. Field facts show that there are factors deliberately burning forests and land. The purpose of burning the forest is to carry out land clearing in preparation for the clearing of plantation land. (Yulianti and Adji 2018)

Based on the phenomenon that occurs, it is imperative to manage natural resources that control the lives of many people in a sustainable and environmentally friendly manner, which is also a constitutional mandate. The results of the fourth amendment to the 1945 Constitution article 33 paragraph 4 states, "The National Economy is carried out based on economic democracy with the principles of togetherness, efficiency, justice, sustainability, environmental insight, independence, and by maintaining a balance between progress and national economic unity" the constitution mandates that forest governance, and peat must be designed for economic progress, environmental sustainability and social justice.

The large amount of peatland that was initially not used, and most of it became unproductive idle land, can be managed properly and can contribute to improving the welfare of the community. This illustrates that there are still efforts to manage peatlands in a potential way that can be utilized by the community. Of course, the wise use of peatlands requires a good communication strategy, the application of appropriate technology and proper management to be a step in maintaining the sustainability of the function of peatlands in supporting sustainable development, which can encourage regional economic growth.(Sumantri, et al, 2013).

Utilizing peatlands in Riau Province is not only the responsibility of the government, but also a concern of the private sector, one of the parties involved is PT Pertamina (Persero) Refinery Unit (RU) II Sungai Pakning. PT Pertamina takes part in the effort to manage peatlands as well as in efforts to deal with forest fires that often occur in this area, through its Corporate Social Responsibility (CSR) program. The company is not only profit-oriented in the financial aspect, but includes social and environmental aspects or what is called the triple bottom line. The synergy of these three elements is the key to sustainable development, which contributes to the welfare of the surrounding community, especially focusing on social and environmental aspects that require assistance.(Gunawan, 2008). Currently the CSR program has been directed to various community empowerment programs, to contribute to improving the welfare of the community as a philanthropic responsibility to be a good coporate citizen whose ultimate goal is to improve the quality of life(Önday 2016).

One of the programs is the management of the Community Empowerment-Based Land and Forest Fire Mitigation Program which is prioritized in the location of Ring 1 in the company's operational area. The mitigation program carried out is by empowering the Fire Care Community (MPA), which is a volunteer group specially formed to respond to, prevent and extinguish forest and land fires at the village level. (Sitorus and Hidayat 2020). Apart from preventing forest fires, the aim of managing this program is to improve the community's economy.

Management carried out by the company in the form of CSR is the use of peatlands through programs designed by the company through planning based on community problems, needs and potential of the existing area. The company's commitment is to assist and nurture the community to become an independent village whose goals are also in line with the company's targets. The community is the main actor in peat restoration and conservation whose management is community-based, which aims to make the community experience directly preventing forest fires and take part in the peat restoration program.(Widhagdha, Wahyuni, and Sulhan 2019)This is in accordance with the ecotourism development policy that has been regulated in the Minister of Home Affairs Regulation Number 33 of 2009 concerning Guidelines for the Development of Ecotourism in Regions (Government 2009).

Community empowerment programs aim to make people have the power, strength or ability in physical and material aspects, economics, institutions, cooperation, intellectual strength and joint commitment in applying the principles of empowerment. These goals form individuals and 
communities to become independent, including the independence of thinking, acting and controlling what they do(Widjajanti 2011), form a pattern of social relationships that are useful for realizing the empowerment of rural communities, (Santosa and Priyono 2012). CSR programs in community empowerment have a very positive impact on the company's image(Rasyid et al. 2015), community empowerment as well as a social conflict resolution strategy (Widhagdha and Hidayat, 2020). This empowerment approach is measured by the ability to explore the unique potential, wisdom, values and culture of the local community. This is in line with that environmental communication(Cox, 2010) which seeks to enhance the ability of society to respond appropriately to environmental signals relevant to the well-being of human civilization and natural biological systems (Yasir 2020)

CSR activities are part of marketing and corporate image, which focus on solving problems faced by society (Widhagdha, Wahyuni, and Sulhan 2019). Through a communication model based on local wisdom, the company together with friendship forums and group discussions emphasize building understanding, agreement, cooperation and collaboration. Even social media is used to send and receive information, as well as to strengthen social relations and ties with companies, as well as to develop managed tourist destinations.(Bakti et al. 2018).

PT. Pertamina RU II is committed to disseminating and managing company-managed peat ecotourism. Attention to the environment is a priority part of developing nature tourism as an effort to conserve nature. This form of company concern must of course be supported by the local government. In accordance with the objectives of national development, namely to realize national development policies and regional development in the field of tourism, efforts are needed to formulate a comprehensive tourism development policy and tourism communication planning. A tourism development strategy that is not oriented solely to an economic approach but is directed towards an environmental, cultural and community empowerment approach. This empowerment approach is measured by the ability to explore potential uniqueness, wisdom, the values and culture of the local community. It is in line that environmental communication seeks to improve people's ability to respond appropriately to environmental signals that are relevant to the wellbeing of human civilization and natural biological systems(Cox 2010). Therefore, the comprehensive solution chosen by the company and the government is peatland restoration (Arifudin et al. 2019).
Based on existing reviews, without proper communication, the management of CSR programs for economic and environmental empowerment will face many problems. It must be communicated and synergized with the community. Communication besides being able to generate community participation, is also able to empower community members not to remain silent as passive recipients, but can also be an active source of information. Departing from this phenomenon and study, this study seeks to explore the management of community empowerment-based CSR programs in the development of peatland ecotourism. As for the purpose of this research is to examine various plans, implementation and evaluation stages in the management of CSR programs based on community empowerment in the development of peatland ecotourism (RESNAWATY, 2019).

The analysis was carried out using the Community Based Tourism (CBT) model.(Sunaryo, 2013)which is a tourism development planning strategy oriented to the empowerment of local communities as development subjects. Community empowerment efforts can be carried out through 3 main principles, namely: 1) Involving community members in decision making; 2) There is certainty that local communities receive benefits from tourism activities; 3) tourism education for local communities. The three principles are then applied to development in community empowerment efforts.(Sunaryo, 2013)

\section{METHOD}

This research uses a descriptive qualitative approach, with data collection techniques through observation, interviews and documentation. The research was carried out in Bukit batu sub-district, Bengkalis Regency, as an area for PT Pertamina's peatland CSR program assistan. The types of data needed in this study include primary data and secondary data. Primary data were collected through in-depth interviews, observation and Focus Group Discussion (FGD). Secondary data were collected by means of tracing accompanied by analysis of related secondary data. Sources of informants were determined based on purposive technique, namely determined based on criteria, namely the manager of the CSR / CDO program of PT Pertamina UP II Sei Pakning, Fire Care Community groups, and community groups that play an important role in peatland management. The data collected is processed and analyzed using the interactive Model of Analysis(Creswell, 2017). The data that has been analyzed are presented in a descriptive qualitative description which is arranged systematically. 


\section{RESULT AND DISCUSSION}

\section{Community empowerment-based CSR programs in the process of developing peatland ecotourism}

The development of tourism is currently very fast and diverse, one of which is peat ecotourism, so that it can be developed into an attractive tourism destination and become a major tourist destination. Currently, tourists prefer natural tourism combined with community participation. Nature tourism or ecotourism also involves local communities in its management, can provide economic benefits to the community or local government. In accordance with the Regulation of the Minister of Home Affairs Number 33 of 2009 concerning Guidelines for Ecotourism Development in the regions, ecotourism development must empower local communities in accordance with the principles of ecotourism, namely the active role of the surrounding community in planning, utilization, and controlling ecotourism by respecting the socio-cultural and religious values of the communities around the tourist areas. With the development of ecotourism, the community is empowered through tourism activities. According to Nugroho(Winarto, 2019), ecotourism is a tour that is responsible for the preservation of nature, culture, and contains educational elements. Development and management of ecotourism is one of the initiatives initiated by the company in its efforts to mitigate fire disasters in Riau Province.

In principle, there are two main characteristics of ecotourism, namely the input environment and the output environment. Inputs are net costs or benefits to the natural and social environment. In addition to the nature and culture offered in an ecotourism product, there are outputs obtained from these activities both for the environment and for the social, especially for the community(Agustini et al, 2014). This can be seen from Pertamina's CSR program in developing peatland ecotourism with community involvement from the initial management process to the present. This involvement is through community empowerment around ring I of the company's operational area, namely in the Bukit Batu District, Sungai Pakning.

The existence of PT Pertamina in the province of Riau plays a role in efforts to handle land and forest fire disasters through the Corporate Social Responsibility (CSR) program by implementing a community empowerment-based land and forest fire mitigation program, especially in the company's Ring 1 location. This mitigation effort is carried out by empowering Masyarakat Peduli Api (MPA), a volunteer group specially formed to respond to, prevent and extinguish forest and land fires at the village level.

Initially, most of the people in Bukit Batu Subdistrict thought that peatlands were considered to be disastrous, because what was in the people's minds was often forest fires during the dry season, which peaked in 2013 to 2015 when large-scale peatland fires occurred. This has resulted in smog which not only disrupts people's daily activities, but also has an impact on the potential for harvests and high health problems due to respiratory infections (ISPA). Seeing these conditions, PT Pertamina through its CSR program pays attention to changing the minset that was originally a disaster into productive land.

The important reason for the company PT. Pertamina (Persero) RU II Sungai Pakning carries out Corporate Social Responsibility (CSR) activities, namely companies need a conducive atmosphere to be able to carry out sustainable production activities. Knowing the socio-culture of the local community will greatly assist in adapting and living side by side in a peaceful and mutually beneficial manner(Irwan Gani, Muliati 2015).

One important concern for companies in understanding environmental conditions in operational areas, especially ring I, is the problem of handling forest fires on peatlands. The impact of various fire prevention programs will be achieved through behavior change, because alternative practices without burning require large labor and resources. Fire prevention programs can help villagers to adapt to managing land without burning, as well as be sufficient and improve the community's economy, as well as being the key to the success of the sustainability of results through various CSR program activities, one of which is how to develop peatlands into tourism products. which is studied in this research includes the planning stage, the implementation stage and the monitoring or evaluation stage.

\section{Planning Stage}

The management of peatlands into ecotourism is carried out through the stages of initiation, reflection or action and monitoring(Purnomo, el all 2020)(Purnomo 2020)(Purnomo 2020)(Purnomo 2020). Before implementing various programs, first identify community problems and then recommend solutions. The company, through its CSR program, identifies problems in the field by surveying burned areas. Research is carried out by Pertamina's Community Development Officer (CDO) to establish communication through field visits, identify problems and sit down with the community. The purpose of 
the survey was to obtain field data and understand the problems faced by the community regarding biophysical, social or livelihood issues. At this stage, the problems faced by the community are identified collectively, then describe a plan to address community problems.

At stage mIn conducting this participatory action research the company conducts research, facilitates and prioritizes land development without burning. Support and assist local communities to select and implement alternatives to land clearing without burning and provide an overview of sustainable business models as part of fire prevention and peat restoration, risk reduction and strengthening traditional knowledge practices in driving community-based initiatives (Sidiq \& Achmad, 2020).

Participatory mapping was also carried out with village communities to identify areas affected by firesIn this area there is already a farmer group called the Tunas Makmur farmer group. This group later became the embryo of group assistance by the company.

Initially, most of the people in Bukit Batu Subdistrict considered peatlands to be disastrous, because forest fires often occur during the dry season. Seeing conditions like this, PT Pertamina through its CSR program pays attention to changing the minset that was originally a disaster into productive land. This is a local indicator designed to monitor implementation in implementing plans in a participatory manner through empowerment.

Community empowerment is an effort aimed at providing power (empowerment) or strengthening (strengthening) to the community. Community empowerment can also be interpreted as the ability of individuals to unite in the aim of finding new alternatives in development in building the empowerment of the community concerned. (Mardikanto and Soebiato 2015). The initial step is to prepare community groups to play a role in dealing with forest and land fires by strengthening the Fire Concerned Community (MPA) group. The problem of forest fires cannot be solved alone by the government or companies by only using their authority and resources and equipment. The spread of forest and land fires in conservation areas, and cultivation areas that are under concession control and on lands managed by the community make it difficult to extinguish, exacerbated by climatic conditions, dry biomass deposits, and hydrological conditions that actually trigger fires. Therefore it is necessary to have cross-sectoral collaboration and participation of various parties including the community in dealing with forest and land fires.
CSR collaborates with the Fire Concern Community (MPA), which has 26 members to map fire prone points, and plan preventive programs by involving the community. One of these programs is called the Kampung Peat Berdikasri program, PT. Pertamina involved the community, starting from adding extinguishing equipment, establishing the Community Communication Forum for Fire Care (Forkompa) to extinguishing training and fostering nine elementary schools with an environment-based curriculum in Bukit Batu District by instilling the values of Kampung Gambut Berdikari from an early age including prevention and utilization. burned land. Development of peat forest into the Peat Arboretum as an educational facility managed by the community.

One of the CSR programs implemented by the company Pertamina RU II Sungai Pakning is located in Kampung Jawa which is still part of the Ring 1 area. The program implemented is adjusted to the environmental conditions and empowers the community and social mapping (social studies) carried out by the company. Peatlands that are considered to be of no benefit to the surrounding community are actually capable of improving the economy for the surrounding community, which includes social and environmental aspects.

PT Pertamina and the local community have initiated a community-based land and forest fire (Karlahut) mitigation program. Companies work with communities to understand the economic, social and environmental dynamics that cause forest and land fires, and their implications. CSR is carried out by supporting and assisting local communities to select and implement alternatives to land clearing without burning and provide an overview of sustainable business models as part of fire prevention and peat restoration efforts, and risk reduction and strengthening of traditional practices and knowledge in community-based initiatives.

The company classifies land into three types of land management, namely; public land, which is land owned by the village and currently being managed by the Fire Care community (MPA) is also called the Ring 1 area. Co-management land; that is, land that is privately owned, but managed by communitybased groups, for example farmer groups. Private land, owned and managed by a farming family. This model of land management began in 2015 with stages through a clear program that the company had planned as a companion.

\section{Implementation Stage}

Implementation of the CSR (Corporate Social Responsibility) program is a form of corporate effort 
in integrating economic, social and environmental aspects into company policies, strategies and operations.(Arham 2016). One of Pertamina's Corporate Social Responsibility (CSR) programs in the environmental sector as a sustainable environmental management effort is the management of peatlands in the Sei Pakning area which is prone to burning

The implementation of a series of Corporate Social Responsibility programs is an increase in corporate awareness of PT. Pertamina in carrying out the development of peatland ecotourism. This can be seen from the community's concern for the safety of the area's environment from forest fire disasters which are subscribed to every year, and have stages including socialization in each program implementation, program implementation through the selection, survey, and monitoring or program evaluation stages. The program implementation stage is carried out, namely:

1. Planting Typical Peat Trees on Burned Lands

In managing the peat ecosystem, it is important that the local community is involved. This management is not only for financial gain, but indirectly for the restoration of the peat ecosystem itself, namely saving the environment. Therefore, environmental services, especially ecotourism, have the potential to be developed in the peat ecosystem. PT Pertanian sees this as an opportunity for the development of ecosystem-based tourism products tailored to the local wisdom of the community around the peat forest in Bukit Batu District, Bengkalis Regency, Riau Province.

Almost every year the Pakning river area of Bukit Batu District experiences forest fires. Based on the peatland map from Wahyunto et al. (2003) the peatlands in this area are categorized as peat with a depth of $50-100 \mathrm{~cm}(1,132 \mathrm{ha})$ and $400-800 \mathrm{~cm}$ (5,594 ha). Nearly $70 \%$ of deep peat $(400-800 \mathrm{~cm})$ is located in permanent production forest. Housing areas and smallholder plantations are located on shallow peat with a depth of $50-100 \mathrm{~cm}$. These smallholder plantations are located on deep peat with a depth of more than $400 \mathrm{~cm}$.

Participatory mapping was carried out with village communities to identify areas affected by fires. There are some communities who do not know that their land has a very high risk of burning, and are not aware of the causes of these forest and land fires. Therefore, PT Pertamina RU II created a program namedKampung Peat Berdikari which is part of CSR Pertamina RU II Sungai Pakning. In carrying out the Kampung Gambut Berdikari program, Pertamina involved the community from adding extinguishing equipment, establishing fire-care community communication forums (Forkompa), to extinguishing training. The community is also involved in the use of burned land through pineapple cultivation and the processing of pineapple products such as chips, lunkhead, sweets, and jam.

Planting on the ex-burnt land was carried out together with the village community, especially the Tunas Makmur Tani Cooperative and the Fire Care Community Group (MPA). The aim of the activities carried out by the company's CSR through CDO with the community is in addition to changing the behavior and mindset of the community, it is also changing the bush that is prone to burning into productive agricultural land and reducing the risk of peatland fires.

Initially the village community were horticultural farmers, in 2010-2015, the area experienced drought and the impact of fires, eventually the community fell out of enthusiasm for farming. The company, through its CSR program, identifies problems in the field by surveying ex-fire areas. Based on the mutual agreement, an experiment was carried out on planting pineapples on burned peatlands. The experiment began in 2017 with a trial planting area of 0.5 ha. It turned out to be successful and so on, it increased its planting on underbrushed community lands to be managed into productive land. In 2018 the additional planting was 5 ha. After the success, the effect is the enthusiasm and desire of the community to be willing to cultivate land planted with pineapples, in 2019 the addition of pineapple planting covering an area of 10 ha.

The first year produces 7 thousand to 8 thousand fruit per hectare. There are three categories of harvested pineapples, namely grade A pineapples which are of good quality and large in size, sold in markets. Grade B is the middle class, some are sold in the market and some are processed into food products. Grade $\mathrm{C}$ is a small fruit that does not sell directly in the market, used as food products such as pineapple chips, pineapple dodol, pineapple jam, and souvenir products for visitors who come to the peat arboretum ecotourism area and pineapple gardens managed by the Tunas cooperative group. Prosperous. Currently, 4.5 hectares of peatland already planted with pineapples can generate IDR 10 million per hectare.

The assistance provided is in addition to assistance, as well as land clearing and nurseries. Initially pineapple seeds were purchased from other areas, but now the nurseries are independent from farmer groups. A form of company assistance by facilitating and bringing in trainers of pineapple 
farmers from Subang with the aim of sharing knowledge and experience not only about how to farm pineapples, sharing problems with good seeds so they can produce good and quality fruit, as well as a faster harvest period, and produce fruit. which is sweet, also so that farmers have insight and experience on how to manage it so that pineapples can be processed into food and souvenirs in order to increase farmers' income.

Apart from pineapple plants, it also leads to reforestation of burnt land, namely perennials such as durian, matoa, jengkol, and soursop trees. These trees were chosen because in addition to having economic value, they also do not require sustainable land management such as burning peatlands for planting. In 2019, pineapple farming will become Pineapple Zero Waste which allows group members to process all parts of the pineapple plant into economically valuable products. According to the results of interviews with the head of the Tunas Makmur group, there are currently 43 group members, among which members consist of housewives and in carrying out their duties they are divided into 3 sub-programs for Kampung Peat Berdikari, namely Peat Arboretum Area, Pineapple Farming, and Processed Pineapple Plants.

The Kampung Gambut Berdikari Program aims to resolve peatlands in the Sungai Pakning Bengkalis Riau area to become a sustainable source of livelihood for the community and have added value to the environment by applying the concept of zero waste. One of the goals is to change the mindset of peatlands which were previously known as the source of the haze disaster, but have economic potential in the form of pineapple farming which results in the welfare of local communities by empowering local MSMEs to be managed in a sustainable manner.

\section{Environment-Based School Curriculum}

PT. Corporate Social Responsibility (CSR) Program. Pertamina implements the Pertamina teaching program in elementary schools. The curriculum applied is the Love Peat School Curriculum, the aim of which is to solve the problem of peatland fires that often occur in Riau Province. Love for the environment needs to be instilled from an early age a love for peatland through an institutional curriculum systematically so that it will give birth to a generation of environmentalists.

Pertamina also fostered nine elementary schools in Bukit Batu District by instilling the values of Kampung Gambut Berdikari from an early age. In its implementation, the 25 elementary schools (SD) have an environment-based curriculum that raises issues of preventing land and forest fires, as well as utilizing the potential of peat areas. What is interesting is that in practicing these values of loving the environment it is directed to develop peat forests into a Peat Arboretum as an ecotourism education or education.

The Love Peatland School Curriculum Program was started in 2017, this program aims to give birth to an Adiwiyata environmentally friendly school and to produce literature on peatland management. Based on the analysis, for the success of this Peat Love School program PT Pertamina has budgeted its CSR program to 25 schools with 3,750 students and teachers amounting to Rp. 627 million.

Environmental-based curriculum development planning has been clearly formulated, the basis for the policy is Adiwiyata based on the Joint Decree of the Ministry of Environment and National Education. This program functions as an educational tour because it has become a pilot curriculum throughout Indonesia. Peatland tourism is developed as a means of education and tourism, especially for the younger generation to introduce the function of land as the main support for the ecosystem. This program is an integration with various approaches ranging from economic empowerment, tourism, health, and land fire management and fostering fire-care communities to be trained and certified.

The implementation of the Cinta Peatland School curriculum is in synergy with other PT Pertamina fostered groups as student learning locations, such as Pineapple Farming, Peat Arboretum and Mangrove Conservation Area to be used as student facilities. Integrated curriculum implementation with varied environmental learning models and real practice in the field supported by Adiwiyata indicators, namely the development of environmental-based school policies, participatory activities, and supporting facilities.

Currently the Cinta Peatland School Curriculum is being prepared by a digital platform that is websitebased as an environmental e-learning, with the aim of widening the impact and benefits in various areas prone to forest fires. The children are facilitated for education provided in the Peat Arboretum as a place to learn directly with nature.

\section{Peat Arboretum Development}

One of the efforts of the CDO Pertamina RU II is the development of the Peat Arboretum which is carried out in collaboration with the Fire Care Community (MPA) and the existing Tunas Makmur Sungai Pakning Farmer Cooperative. Although the initial focus was on pineapple farming, an idea emerged from the company and farmers to develop a 
peat arboretum. Land that is still in the form of forest is developed to be used as an educational tour, the initial purpose of which is as a place for discussion and gathering as well as monitoring activities for companies in mentoring. The arboretum is also used as a place for dosing honey by the community.

The arboretum is on 1.1ha of native peatland that has survived the fires. PT. Pertamina Sungai Pakning together with the Community Care for Fire (MPA) group and the Tunas Makmur Farmer Group first identified various typical peat plants that survived forest fires, while at the same time trying to cultivate typical peat plants, so they would not become extinct. There are tree species in the area such as meranti, ramin, suntai, durian, mentagor, and medang trees, although the population of tree species is small, there are also many other trees because they are preserved with the aim of the learning process of elementary school students. know plants. There are also types of animals such as gibbons, langurs, long-tailed macaques, monkeys and sun bears. These types of animals have also become rare.

This arboretum land belongs to the community and then managed and built tracks to be used as tourist attractions, and there are built pavilions and places for games such as outbound. This peat arboretum ecotourism seeks to maintain the existence of existing forests to be protected from fires by utilizing and cultivating existing plants. Plants in the endemic category that can grow well on peatlands that are already scarce and are currently protected by the diarboretum, such as semar bags, jelutong, and red palms. The types of trees in this arboretum are cared for and given a name for each tree to function as a learning center for school children.

The function of the peat arboretum apart from being ecotourism, is also as an educational tour or education for the natural environment which is used as a learning tool for school students around the Pakning River area as partners, and even 25 elementary schools that have become members or partners have implemented curricula with book guides produced and compiled. by the company PT. Pertamina RU II in three Districts, namely Bukit Batu District, Siak Kecil District and Bandar Laksamana District. Besides being carried out by farmer groups who interact with visitors, arboretum ecotourism activities also aim to train the farmer groups' habits to get used to behaving happily, proactively friendly when receiving guests or tourists.

The current visitors, not only from students, but also from among students, researchers from universities have made the peat arboratum as a field learning laboratory. The general public as tourists, many who come from both nearby and outside areas who are aware of the peat arboretum ecotourism on the Pakning River. In addition to education, peat arboretum is also useful for increasing community income, providing income for the management group, namely from selling entrance tickets, selling food, souvenirs made from pineapples and plants cultivated by farmer groups to take home visitors (Sidiq, Rd. Siti Sofro, Jalil, A \& Achmad 2021).

Currently the public's interest is increasing to visit, each month the visitors continue to increase and the average visitor is around 1,500 per month, from various backgrounds, especially students and students. Even on weekends, many families visit to feel the sensation of back to nature and witness firsthand the endemic flora that are protected and are already rare, such as the semar bag. The high interest of the community has an impact on the income of the community groups who manage it reaching Rp. 15 million each month.

\section{Monitoring Stage}

Evaluation is an effort to assess the overall number of results from a CSR (Corporate Social Responsibility) activity or program. The monitoring concept will focus more specifically on the assessment of certain things, such as the situation over time when the program is still in the process of implementation. In connection with the concept of evaluation, three forms of evaluation can be distinguished, namely formative evaluation, summative evaluation, and empowerment evaluation.(Prayogo 2011). Formative evaluation (formative evaluation) is an assessment to improve program performance or performance, this is done while the program is still or is running. This kind of evaluation is mostly carried out in the middle of a program, intended to ensure that the program runs according to plan and schedule so that goals can be achieved on time.

Summative evaluation is evaluation at the end of the program to ensure that the program that is executed succeeds or fails according to program objectives. Such an assessment is needed to ensure that if the same program is applied in another place with a relatively similar context, the same level of success will be obtained. Therefore, in summative evaluation, the assessment is carried out thoroughly on the planning elements of the objectives to be achieved. The third form, namely empowerment evaluation, is an assessment to see the level of success of an activity or program according to empowerment measures, such as capacity building, the ability to manage organizations, increase user awareness and other aspects related to the concept of empowerment. 
Different forms of evaluation are also determined by how the CSR program approach is used. Because differences in program approaches are influenced by perspectives and approaches, interests and objectives to be achieved, evaluation of the success of the program must refer to these aspects. The success rate of the program according to the perspective of locality development, for example, will be different from the perspective of social action and social planning (Botes and Rensburg, 2000; Gunn \& Hazel, 1991).(in Prayogo 2011).

Because the objective of the program according to the social action perspective with the objective of the CSR program is to make social changes, to improve the position of society towards other institutions so that the measurement of the success of the program will be emphasized on the level of empowerment achieved by the community concerned. According to this approach, the form of evaluation used is a form of empowerment evaluation by looking at how the community's capacity building in carrying out social movements independently.

In the social planning approach, the main goal that PT. Pertamina is solving the problem of forest fires that have an impact on society, such as problems, education, health or the like. For this purpose, the success of the program is seen from the degree to which the problem solving in question can be achieved, so that the relevant evaluation forms are used which are formative and summative evaluation forms. Because the CSR program approach refers more to social planning, the most widely used form of program evaluation is formative and summative. Formative evaluation is intended to assess the achievement of the ecotourism program in accordance with the plan, while summative is used to ensure that the program can be applied elsewhere. In this case the local community maximizes the profits of the company and has control over the ecotourism in their area. In the last decade, massive forest and peatland fires have inevitably caused air pollution and land degradation with enormous economic, social and environmental impacts.(Winarto, et al: 2019).

The supervision stage is not only carried out by PT Pertamina, but also involves the community by giving trust to the community to monitor the activities of the community itself. In this case Miftah and the team as CDO of PT Pertamina always monitored by sitting together and sharing stories with farmer groups to control ongoing activities. This activity is always carried out in the peat arboretum education pavilion, or in the cooperative canteen of the Tunas Makmur cooperative. This program has been successful in stopping forest and land fires since 2015 so that it can become a pilot for other areas with the same problems. Increasing visits from other villages, sub-districts and districts to learn to control forest and land fires together and provide added value economically to the community.

PT Pertamina's positive effort is to conserve peatlands based on community empowerment through the Peat Arboretum, Conservation and Peatland education program by empowering the community. This means that it is conserved, used by the surrounding community.

The results of the explanation from the research on the management of PT Pertamina's CSR program are in accordance with the implementation of the Community Based Tourism (CBT) Model. Application of CBTis a tourism development planning strategy that is oriented towards community empowermentfour. In line with the theory developed by Sunaryo(Sunaryo 2013)that there are three main principles in the tourism development planning strategy in the CBT concept, namely; 1) involve the community in decision making, 2) there are benefits that are felt directly by the local community, and 3 ) tourism education in the local community.

Decision-making involving the community is carried out by PT Pertamina by holding regular discussions and meetings on a regular basis to discuss developments and field problems between the manager and the community, namelyThe Fire Care Community (MPA) and the Tunas Makmur Farmer Group, village elders and local community leaders.

Participation of the community in making decisions is not only to discuss problems and to find solutions, but also to know the society's perceptions regarding the benefits that have been obtained. These benefits must really be felt by the community because the tourism service industry will not be said to be good if the benefits cannot be felt directly by the surrounding community.

There are benefits that can be felt by the surrounding community (Astri, 2012), especially for people who live in the company's operational areas that are in ring I. These benefits include creating new jobs for the community, such as the production of processed souvenirs made of pineapples, souvenirs from pineapple leaves, and small shops around the location. ecotourism in accordance with the program launched by the manager, namely one day on the Pakning River with a package offered, namely tours to pineapple plantations, followed by the Peat Arboretum as an educational tour and completed by being taken to the souvenir center of the farmer groups. 
Tourism education is in accordance with the concept Community Based Tourism (CBT) Model which is a tourism development planning strategy (Elfianita 2016) the company has also done this through the Environmental-Based School Curriculum program. The management of this program is carried out with the hope of motivating and instilling the values of loving the environment, which can be applied and practiced by future generations directly or indirectly.

\section{CONCLUSION}

Program management Corporate Social Responsibility Pertamina UP II based on community empowerment in the development of peatland ecotourism has gone well and has produced positive impacts on the community in a sustainable manner. The management is in accordance with the ecotourism development policy which has been regulated in the Minister of Home Affairs Regulation number 33 of 2009 concerning Guidelines for Ecotourism Development in the Regions. ProcessThe management is carried out in three stages, namely the planning stage, the implementation stage and the monitoring stage. Programs developed start from preventive, educational, to rehabilitative efforts. Preventive efforts directly involve the community about the importance of instilling a culture of love and protecting the environment by strengthening the forumcommunication community care (Forkompa). Educational efforts such as implementing programsenvironmentally based school curriculum implemented in schools and peat arboretum ecotourism. Rehabilitation efforts by planting productive and endemic trees in burnt area.

\section{REFERENCES}

Agustini, N.W. \& Adikampana, I.M. (2014). Pemberdayaan Masyarakat Dalam Proses Pengembangan Ekowisata Taman Sari Buwana Di Desa Tunjuk, Kecamatan Tabanan, Kabupaten Tabanan, Bali. Jurnal Destinasi Wisata 2, (1): 46-56.

Arifudin, A., Syahza, A., Kozan, O., Mizuno, K., Mizuno, K., Isnaini, Z. L., \& Hasrullah, H. (2019). Dinamika Penggunaan, Kebakaran, dan Upaya Restorasi Lahan Gambut: Studi Kasus di Desa Tanjung Leban, Bengkalis. In Unri Conference Series: Agriculture and Food Security, 1, 40-45).

Astri, H. (2012). Pemanfaatan (CSR) Bagi Peningkatan Kualitas Hidup Manusia Indonesia. Aspirasi: Jurnal Masalah-Masalah Sosial. 3, (2), 151-165.
Agus, F., Wahyunto, Sosiawan., H., I G.M. Subiksa, Prihasto, and Irsal Las Setyanto, Ai Dariah, Maswar, Neneng L. Nurida, Mamat H.S. (2014). Pengelolaan Berkelanjutan Lahan GambutTerdegradasi : Trade-Off Keuntungan Ekonomi Dan Aspek Lingkungan. In Balai Besar Penelitian Dan Pengembangan Sumberdaya Lahan Pertanian, Indonesia, 32.

Arham, M. AB. (2016). 'Prinsip Tanggung Jawab Sosial Perusahaan Terhadap Lingkungan Hidup'. In Tanggung Jawab Pelaku Bisnis Dalam Pengelolaan Lingkungan Hidup,

Bakti, I., Sumartias, S., Damayanti, T. \& Nugraha, A.R. (2018). Pengembangan Model Komunikasi Pariwisata Berbasis Kearifan Lokal Di Kawasan Geopark Pangandaran. Jurnal Kajian Komunikasi 6, (2): 217.

Cox, R. (2010). Environmental Communication and the Public Sphare. California: Sage Publication.

Creswell. J. H. (2017). Research Design, Kualitatif, Kuantitatif, Mixed. Yogyakarta: Pustaka Pelajar.

Dody, P. (2011). Evaluasi Program Corporate Social Responsibility Dan Community Development Pada Industri Tambang Dan Migas. Makara Human Behavior Studies in Asia 15, (1): 43.

Elfianita, E. (2016). Pengembangan Pariwisata Berbasis Community Based Tourism (CBT) Di Desa Wisata Limbasari Kecamatan Bobotsari, Kabupaten Purbalingga. Jurnal Elektronik Mahasiswa Pendidikan Luar Sekolah. 5, (3), 1-10.

Gunawan, A. (2008). Membuat Program CSR Berbasis Pemberdayaan Partisipatif Kata Pengantar. Yogyakarta

Gani, I. Muliati, \& Amalia, S. (2015). Pemetaan Masyarakat Sebagai Target Group Program Csr Pt. Pkt Bontang'. Jurnal sosiohumaniora 17(1): 28-34.

Mardikanto, Totok, \& Soebiato, P. (2015). Pemberdayaan Masyarakat: Dalam Perspektif Kebijakan Publik. Bandung Alfabeta.

Özgür, O. (2016). 'The Relationship between Concepts of Corporate Governance, Business Ethics and Corporate Social Responsibility: Situation on World and In'. 91, (3), 37956-65.

Peraturan Pemerintah. (2009). Peraturan Menteri Dalam Negeri Nomor 33 Tahun 2009 Tentang Pedoman Pengembangan Ekowisata Di Daerah. Jakarta: Menteri Dalam Negeri. 
Winarto, P. (2019). Corrective Action Tata Kelola Gambut Di Indonesia Kementerian Lingkungan Hidup Dan Kehutanan Republik Indonesia Menuju Ekosistem Gambut Berkelanjutan. Kementerian Lingkungan Hidup dan Kehutanan Republik Indonesia Direktorat Jenderal Pengendalian Pencemaran dan Kerusakan Lingkungan Direktorat Pengendalian Kerusakan Gambut.

Purnomo, H.; Puspitaloka, D. (2020). Pembelajaran Pencegahan Kebakaran Dan Restorasi Gambut Berbasis Masyarakat. Center for International Forestry Research (CIFOR).

Rasyid, A. Saleh, A, Cangara, H, \& Priatna, W.B. (2015). Komunikasi Dalam CSR Perusahaan: Pemberdayaan Masyarakat Dan Membangun Citra Positif. MIMBAR, Jurnal Sosial dan Pembangunan 31, (2): 507.

Resnawaty, R. (2019). Kontribusi Dunia Usaha Dalam Pelaksanaan Program Pelestarian Fungsi Sungai (Studi Kasus Pelaksanaan CSR Perusahaan Listrik Dalam Program Citarum Harum). Sosiohumaniora 21, (3): 279-86.

Santosa, I. \& Priyono, R.E. (2012). Melalui Pengelolaan Agrowisata. Mimbar 28, (2): 181-90.

Sidiq, R.S.S., Jalil, A. \& Achmad, RWW. (2021). Virtual World Solidarity: How Social Solidarity Is Built on the Crowdfunding Platform Kitabisa.Com. Webology, 18, (1): 192-202.

Sitorus, Hazar, S. \& Hidayat, R. (2020). International Conference Communication and Sosial Sciences (ICCOMSOS) Strategi Mitigasi Kebakaran Hutan Dan Lahan Melalui Pemberdayaan Masyarakat Di Sungai Pakning Kabupaten Bengkalis Provinsi Riau.
Sumantri, B., Fariyanti, A. \& Winandi, R. (2013). 'Faktor-Faktor Yang Berpengaruh Terhadap Kinerja Usaha Wirausaha Wanita: Suatu Studi Pada Industri Pangan Rumahan Di Bogor'. Jurnal Manajemen Teknologi. 3, (12), 252277.

Sunaryo, B. (2013). Kebijakan Pembangunan Destinasi Pariwisata: Konsep DanAplikasinya Di Indonesi. Yogyakarta: Gava Media

Widhagdha, F. M. Wahyuni, H.I, \& Sulhan, M. (2019). Bonding, Bridging and Linking Relationships of the Csr Target Communities of PT Pertamina Refinery Unit II Sungai Pakning. Jurnal Komunikasi: Malaysian Journal of Communication 35,(4): 470-83.

Widjajanti, K. (2011). Model Pemberdayaan Masyarakat. Jurnal Ekonomi Pembangunan: Kajian Masalah Ekonomi dan Pembangunan 12, (1): 15 .

Wahyunto, N. K., Ritung, S., \& Sulaeman, Y. (2014). Indonesian peatland map: method, certainty, and uses. Proceeding Lokakarya Kajian dan Sebaran Gambut di Indonesia, Conference: Pengelolaan Berkelanjutan Lahan Gambut Terdegradasi At: Jakarta

Widhagdha, M.F. \& Hidayat. R. (2020). Pemberdayaan Masyarakat Sebagai Strategi Resolusi Konflik Sosial. Jurnal Pemberdayaan masyarakat. 8, (1), 82-91.

Yasir, Y. (2020). Environmental Communication Model of Farmer Community in Peatlands Ecotourism Development. In Journal of Physics: Conference Series,.

Yulianti, N. \& Adji. F.F (2018). Pengelolaan Lahan Tanpa Bakar ( PLTB ). Bogor: PT Penerbit IPB Press. 